\title{
Impact of the global financial crisis on the Indian economy
}

\author{
Krishna Kumar Jaiswal (Corresponding author) \\ Research Scholar, \\ Humanities and Management Department, National Institute of Technology, Delhi, India \\ Email: krishnakumar@nitdelhi.ac.in
}

Krishna Kumar Dubey

Research Scholar,

Department of Commerce, Indira Gandhi National Tribal University, Madhya Pradesh, India

Email: dubeykrishna1997@gmail.com

\begin{abstract}
$\underline{\text { Abstract }}$
This paper provides a descriptive review of the impacts of the global financial crisis on the Indian economy. While examining the growth in the gross domestic product (GDP), fiscal deficit, exports, imports, Wholesale Price Index (WPI) inflation, and the foreign exchange rates (FX), we find that the GDP has been severely impacted during the crisis period, especially during 2008-09. While the fiscal deficit continuously increased during 2008-09 and 2009-10, the exports and imports declined considerably. The WPI inflation followed a downward trend, and the rupee depreciated by approximately 20 percent during 2008. During 2008-09, the agricultural and industrial growth significantly declined, but the service sector sustained itself. The findings also reveal that the policy initiatives by the Indian government and those by the Reserve Bank of India safeguarded the Indian economy to a large extent.
\end{abstract}

Keywords: Global financial crisis; export; import; inflation; foreign exchange

\section{Suggested citation:}

Jaiswal, K. K., \& Dubey, K. K. (2021). Impact of the Global Financial Crisis on the Indian Economy. International Journal of Accounting, Business and Finance, 1 (1), 15-23.

\section{Introduction}

The financial crisis of 2007-08 in the United States (US) has also known as the global financial crisis and global economic recession. Although it started in the US, it affected the whole world. The world GDP declined by 1 percent. It is considered the worst financial crisis since the 1930s Great Depression. The crisis emerged in the US due to the loose regulatory regime and low-interest rate in the post-dot-com period; easy bank advances with the low creditworthiness of borrowers create a massive demand in the housing sector. After the US government changed the accommodative policy and increased the interest rate, the burden of equally monthly instalment (EMI) increased on borrowers, which led to borrowers defaulting in the loan payment. In the end, it created considerable losses to the bank and financial institutions. In 2008, the collapse of the Lehman Brothers in September 2008 turned the turmoil into a global crisis.

The Indian economy, although supported with solid fundamentals of the banking system with the controlled regulatory regime, yet the spillover effects of the crisis negatively affected the Indian economy. The gross domestic product (GDP), which has been increasing since globalization, declined from 9.30 in $2007-08$ to 6.80 in 2008-09 after the collapse of Lehman Brothers. Jobs from information technology (IT), business process outsourcing, and financial services declined. The main impact of the spillover effect of crises was the mass withdrawal of foreign portfolio investors from the Indian stock market, which declined from Rs. 66179 corers in 2007-08 to negative Rs. 45811 crores. This created a financial collapse in the Indian stock market, Sensex declined, and economic activities contracted drastically. 
Rupee depreciated in terms of the US Dollar. Export and foreign exchange reserves also declined, which led to an increase in the deficit balance.

This paper provides a brief overview of the performance of different sectors of the Indian economy during the global financial crisis. It also aims to compare the performance of the pre-crisis period to the crises period, analyze the trend of financial indicators during the crises, and review the Indian government's response to overcome the crises. This study aims to contribute to the existing literature on the global crisis, especially its impacts on different sectors of an emerging economy.

\section{Literature Review}

Financial stability issues are receiving increased attention due to the 2008 financial crisis. Several studies have been conducted to assess the impact of the crisis on both developing and developed economies. Mohan (2011) explained that the market could handle any unusual situation, but the global financial crisis proved him wrong, and he suggested that banks and financial sector players be well-governed while maintaining flexibility in their operations. Das (2012) describes that the major causes of the global financial crisis were a subprime mortgage, excessive leverage, securitization, and repackaging of loans. They analyzed the impact on the agriculture and fisheries industry and concluded that exports declined sharply during the crisis, which created a slump in the fishery industry. Even in the age of globalization and free trade, he suggested being self-reliant and self-dependent. Pandey \& Jaiswal (2014) suggest that the crisis was a past-borne issue and has been neglected for a long time before. According to (Prasad \& Reddy, 2009), the Indian economy also faced a decline due to the spillover effect of the crisis. Loss of jobs in the IT sector, exchange rate decline, Foreign Portfolio Investment withdrawal ultimately led to considerable losses in banks and stock markets, yet due to solid banking fundamentals and regulatory regimes, the economy prevented itself from the crisis. He also opined to be self-reliant and protectionist. (Bhatt, 2011), while examining the data of GDP and other factors from 2005-06 to 2010-11, found that the financial crisis in the US had some negative effect on the Indian economy and that the significant effect of the crisis was a massive outflow of FIIs that led to the collapse of the stock market and depreciation of rupees. He stated that to curb the negative effect of the crisis, the government should inject liquidity into the market and use effective fiscal policy. (Mishkin, 1997) stated that the fundamental causes of financial instability in an economy are asymmetric information and moral hazards, leading to uncertainty, increased interest rate, and problems in banking sectors.

\section{Data and Research Methodology}

The study relied on secondary data gathered from various sources. GDP data was collected from the Reserve Bank of India's website. Fiscal Deficit data was collected from the reports published by the Ministry of Finance, the Department of Economic Affairs, the Economic Division, and the Government of India. The data for exports and imports were obtained from the Ministry of Commerce, Government of India. Other data sources include the reports published by the Department of Industrial Policy and Promotion (DIPP), the National Depository Corporation Limited, and India's Economic Survey. We calculate several variables that yield the study's findings using these data.

The GDP growth is calculated as per equation 1:

$$
G D P_{g}=\frac{G D P_{t}-G D P_{t-1}}{G D P_{t-1}} * 100
$$

where, $\boldsymbol{G D} \boldsymbol{P}_{\boldsymbol{g}}$ is the GDP growth; $\boldsymbol{G} \boldsymbol{D} \boldsymbol{P}_{\boldsymbol{t}}$ is the GDP of the current year (t); $\boldsymbol{G D P} \boldsymbol{P}_{\boldsymbol{t}-\mathbf{1}}$ is the GDP of the previous year ( $\mathrm{t}-1)$, and GDP is the Gross Domestic Product (at constant price). 
The fiscal deficit is calculated as per equation 2:

$F D_{G D P}=\frac{F D_{t}}{G D P_{t}} * 100$

where, $\boldsymbol{F} \boldsymbol{D}_{\boldsymbol{G D P}}$ is the Fiscal Deficit (in \% of GDP); $\boldsymbol{F} \boldsymbol{D}_{\boldsymbol{t}}$ is the fiscal deficit for the current year, and fiscal deficit means the combined fiscal deficit of India's central and state governments.

The export and import growth rate are calculated as per equation 3:

$$
\operatorname{ExIm}_{g}=\frac{\operatorname{ExIm}_{t}-\operatorname{ExIm}_{t-1}}{\operatorname{ExIm}_{t-1}} * 100
$$

where, $\boldsymbol{E x I m}_{\boldsymbol{g}}$ is the export and import growth rate; $\boldsymbol{E x} \boldsymbol{I m}_{\boldsymbol{t}}$ is the export/import for the current year; and $\boldsymbol{E x} \boldsymbol{I m}_{\boldsymbol{t}-\mathbf{1}}$ is the export/import during the previous year.

The change in the foreign exchange rate is calculated as per equation 4 :

$$
F X_{\text {change }}=\frac{F X_{t}-F X_{t-1}}{F X_{t-1}} * 100
$$

where, $\boldsymbol{F} \boldsymbol{X}_{\text {change }}$ is the change in the foreign exchange rate; $\boldsymbol{F} \boldsymbol{X}_{\boldsymbol{t}}$ is the foreign exchange for the current month; and $\boldsymbol{F} \boldsymbol{X}_{\boldsymbol{t}-\mathbf{1}}$ is the foreign exchange during the previous month.

The Wholesale Price Index (WPI) inflation has been collected from the website of the Economic Advisor (https://eaindustry.nic.in/indx_download_0405/yearlyf.xls).

\section{Quantitative analysis and results}

The impact of the economic meltdown on the Indian economy differed from that of the developed world. The Indian economy has suffered some adverse effects from the financial meltdown that appears to have started in the United States in September 2008. Figure 1 presents the trend in GDP growth rate, which was 7.05\% in 2004-05, increased to $9.32 \%$ in $2007-08$, but due to the global financial crisis, it reduced to $6.72 \%$ in $2008-09$. This reveals how emerging economies like India have been affected due to the financial crisis that emerged in the US. The RBI and the Government of India had taken steps to recover from the recessionary effects. In order to increase market liquidity and improve investment and productive practices, the RBI reduced the Cash Reserve Ratio and the Statutory Liquidity Ratio. The government of India had taken fiscal measures to create demand in the economy, and as a consequence, consumption and investment practices improved, and in the end, industry and services sector growth increased, leading to an increasing trend of GDP. In 2009-10, 2010-11, the GDP growth increased to $8.59 \%$ and $8.91 \%$, respectively.

Figure 1: Trend of GDP growth during the period 2004-05 to 2016-17

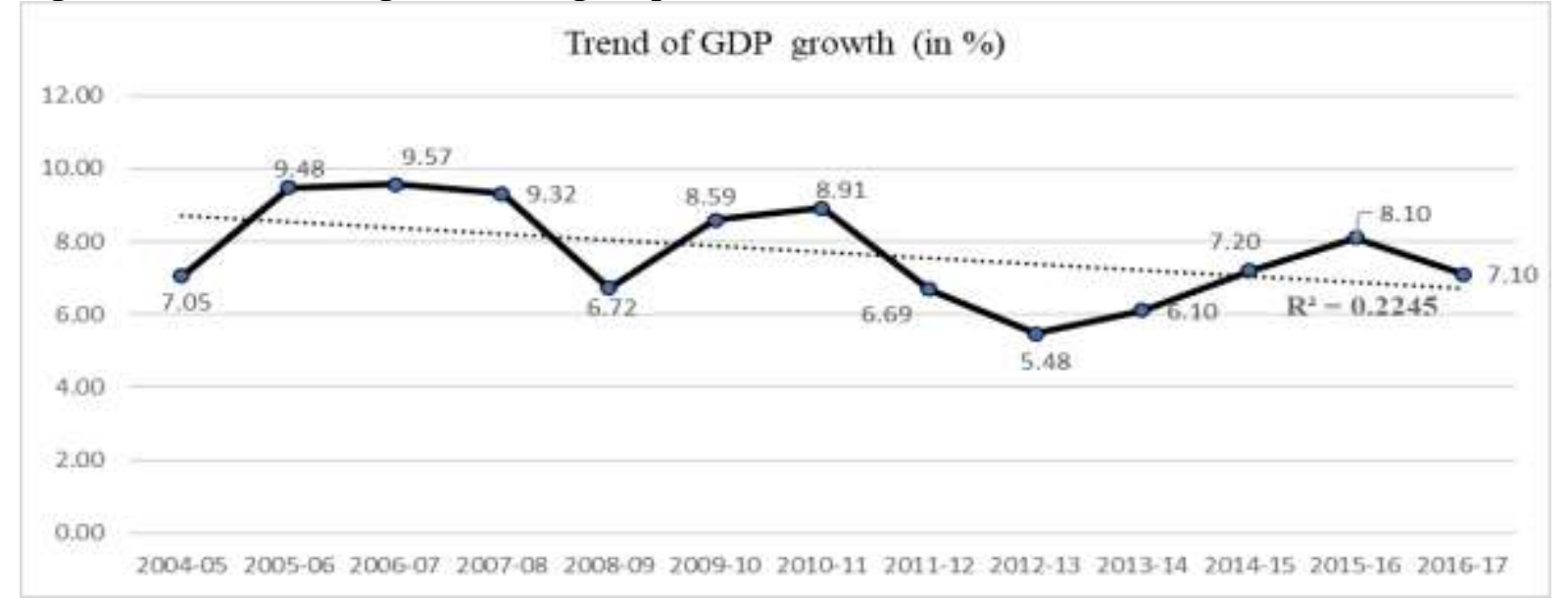

Source: Drawn by the author based on the calculations. 
As per the Economic Survey of India (2013-14), there was some slowdown in GDP growth during 2011-12 to 2013-14; it decreased to 6.69 in 2011-12, 5.48\% in 2012-13 because of the high inflation rate $(9.56 \%$ in $2010-11,8.92 \%$ in $2011-12$ and $7.35 \%$ in $2012-$ 13), high lending rate, and uncertainty in domestic policy. The analysis of the last three years (2014-15 to 2016-17) reveals that the GDP growth rate was convincing, with $7.20 \%$ in 201415, and in 2015-16 and 2016-17, it was $8.10 \%$ and $7.10 \%$, respectively due to government initiatives and financial inclusion practices.

Table 1: Sectors-wise growth rate in Indian economy (in percentage)

\begin{tabular}{cccc}
\hline Year & Agricultural growth & Industry Growth & Service Growth \\
\hline $2004-05$ & 0.18 & 9.81 & 8.28 \\
$2005-06$ & 5.14 & 9.72 & 10.91 \\
$2006-07$ & 4.16 & 12.17 & 10.06 \\
$2007-08$ & 5.80 & 9.67 & 10.27 \\
$2008-09$ & 0.09 & 4.44 & 9.98 \\
$2009-10$ & 0.81 & 9.16 & 10.50 \\
$2010-11$ & 8.60 & 7.55 & 9.67 \\
$2011-12$ & 5.02 & 7.81 & 6.57 \\
$2012-13$ & 1.50 & 3.30 & 8.30 \\
$2013-14$ & 5.60 & 3.80 & 7.70 \\
$2014-15$ & -0.20 & 7.00 & 9.80 \\
$2015-16$ & 0.60 & 9.80 & 9.60 \\
$2016-17$ & 6.30 & 6.80 & 7.50 \\
\hline
\end{tabular}

Note: The sectoral growth rate from 2004-05 to 2011-12 is based on the constant price of 2004-05, and the growth rate after 2011-12 is based on the constant price of 2011-12.

Sources: 1. Key economic indicators August 2018, Central Statistical Office, Government of India. 2. Central Statistical Office May 2014, Planning commission, Government of India. Available at http://planningcommission.gov.in

Table 1 presents the sector-wise growth rate in the Indian economy. Agriculture growth during the financial crisis declined rapidly. In 2005-06, the agriculture growth was $5.14 \%$, which decreased to $4.16 \%$ in $2006-07$, and during $2007-08$, it increased to $5.8 \%$. However, due to the financial crisis, it drastically declined from $5.80 \%$ to $0.09 \%$ in $2008-09$. In 2009-10, it decreased to as low as $0.81 \%$, which presented an accurate picture of the effects of the financial crisis. In 2010-11, the agricultural growth regained momentum and reached $8.60 \%$ because of good Rabi crop production and better food management. Agriculture growth has been very volatile even after the phase of the crisis. In 2012-13, it was $1.50 \%$, and in 2014-15, it was $-0.20 \%$. Deshpande (2017) concludes that factors that affect agricultural output include shrinking agricultural land holdings, reliance on the monsoon, insufficient irrigation facilities, inadequate access to advanced technology throughout all parts of the country, insufficient access to institutional credit to agriculture, issues with procurement activities of food grains, and failure to provide farmers with remunerative prices. Bera (2017) confirms that during 2016-17, the agricultural growth increased from $0.60 \%$ to $6.30 \%$ because of good monsoon, record production of food grain of 272 million, and various government initiatives.

The industrial sector also faced negative impacts due to adverse demand conditions in the export market and suppressed domestic demand from the domestic sector. In 2004-05, industrial growth was $9.81 \%$, which increased to $12.17 \%$ in 2006-07. It reduced to $9.67 \%$ in 2007-08, and during the phase of the financial crisis, it reached a shallow level at $4.44 \%$ in 2008-09. After recovery from the crisis, the industrial growth was $9.16 \%$ in $2009-10$ due to the favorable investment environment created by the government and the RBI through 
monetary and fiscal policy measures. According to the Economic Survey of India (20122013), it fell again in 2012-13 and 2013-14 due to the Eurozone crisis, sluggish domestic investment growth, low corporate sector margins, and a slowdown in credit flow growth. In terms of productivity, Economic Survey of India (2016-2017), industrial growth declined from $9.80 \%$ in $2015-16$ to $6.80 \%$ in $2016-17$, due to the balance of payment problem and depressed private investment cycle. The service sector has also been affected by the financial crisis. However, the impact of the crisis was lower than agriculture and the industrial sector. It declined from $10.27 \%$ in $2007-08$ to $9.98 \%$ in $2008-09$, export of services also declined, especially in the IT sector and outsourcing services. Millions of IT sector jobs were reduced, and the uncertainty factor was very high. After the global financial crisis during 2009-10 and 2010-11, service sector growth was impressive at $10.50 \%$ and $9.67 \%$, respectively. The service sector performance during $2015-16$ was $9.60 \%$ which further declined to $7.50 \%$ in 2016-17 due to deceleration in trade, hotel transport, communication, and services related to broadcasting (i.e., 7.80\%) and financial, real estate, and professional services (i.e., 5.70\%).

Figure 2: Trend of the fiscal deficit during the period 2004-05 to 2016-17

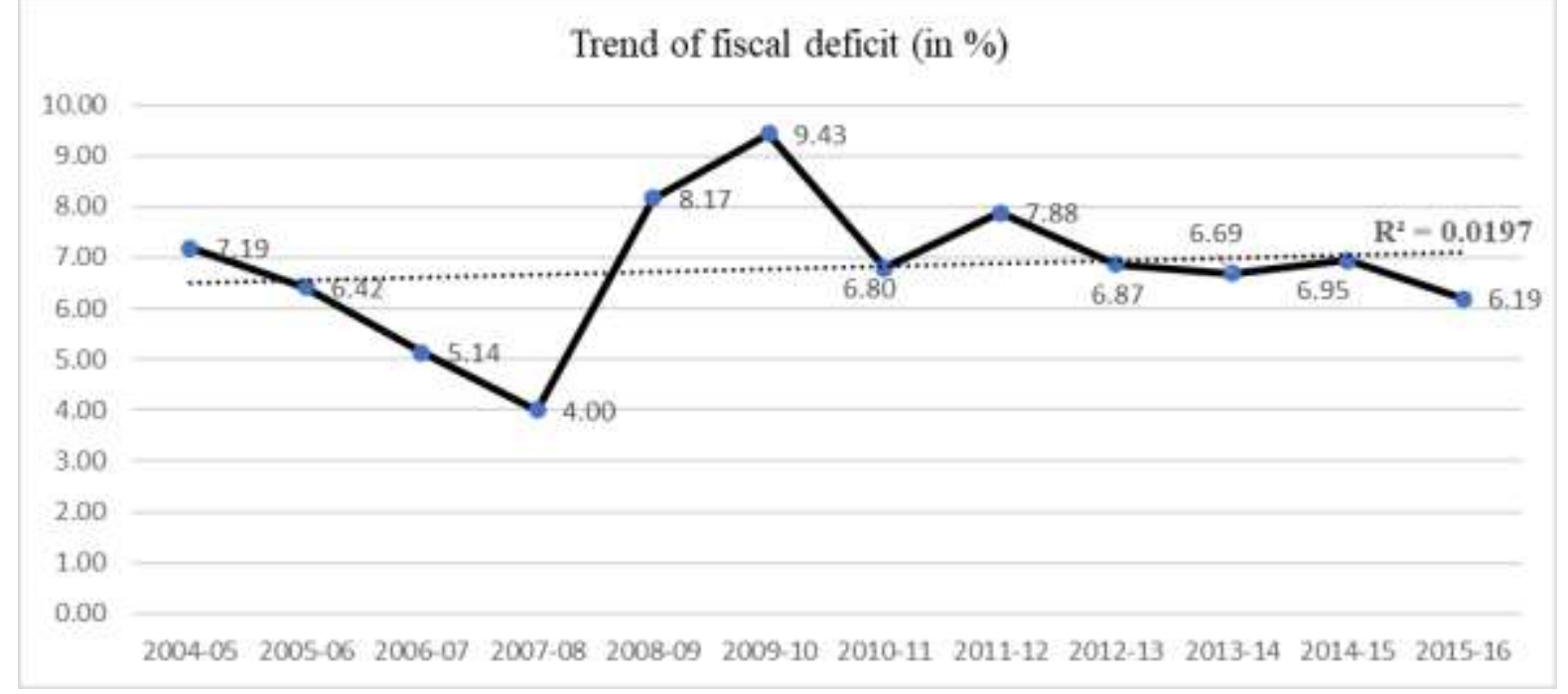

Source: Drawn by the author based on the calculations.

Figure 2 depicts the fiscal deficit from 2004-05 to 2016-17. Kumar \& Joseph (2009), in their working paper about fiscal deficit during pre and post-global financial crisis, present the trend that in the year 2004-05, the fiscal deficit was 7.19\% of GDP in 2004-05, which reduced to $4.00 \%$ in 2007-08. However, during the financial crisis of 2008-09, it increased to $8.17 \%$ in order to maintain the cost (Rs. 30,000 crores) of fiscal stimulus, which the government of India took to create a favorable demand condition in the recessionary economic situation, further in the year of 2009-10 it increased to $9.43 \%$. Gupta \& Singh (2016) concludes that in 2010-11, the fiscal deficit reduced to $6.80 \%$ due to higher non-tax revenue from the telecom spectrum auction. In 2011-12, the fiscal deficit increased to $7.88 \%$ due to higher inflation, rate, tightening of monetary policy, decreased investment, and growth, leading to lower tax revenue. During 2014-15 and 2015-16, the combined fiscal deficit reduced to $6.95 \%$ and $6.15 \%$, respectively. In 2015-16, gross tax revenue collected surpassed the budgeted target of Rs 14,49,490 crores by Rs 10,121 crores, facilitating a reduced fiscal deficit of $6.15 \%$.

The global financial crisis had a significant impact on the global market; as a result, the pace of India's exporting manufacturing industries was severely impacted. After the new economic policy, the Indian economy became more integrated and liberalized with other economies. Exports were rapidly increasing, but the downward trend in the world market, as the consequences of the crisis, badly affected the export trends in India. 
Figure 3: Trend of export and import during the period 2004-06 to 2016-17

Trend of change in Export (\%)

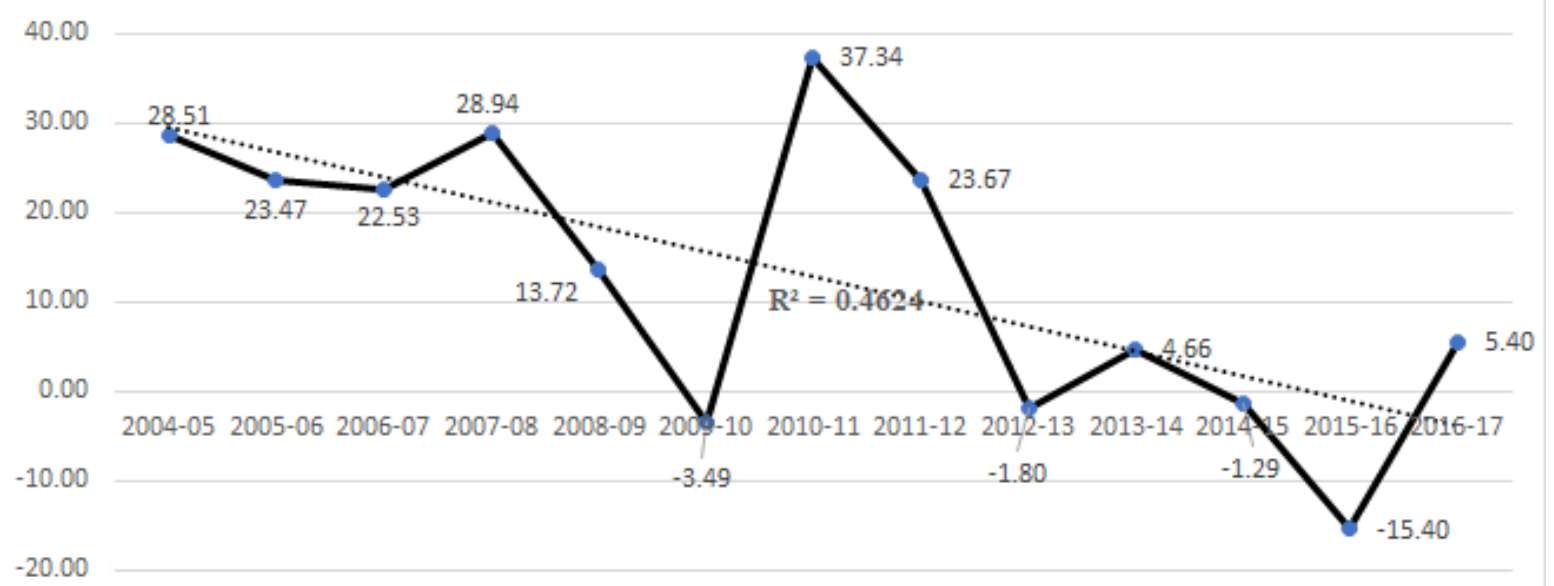

Trend of change in Import (\%)

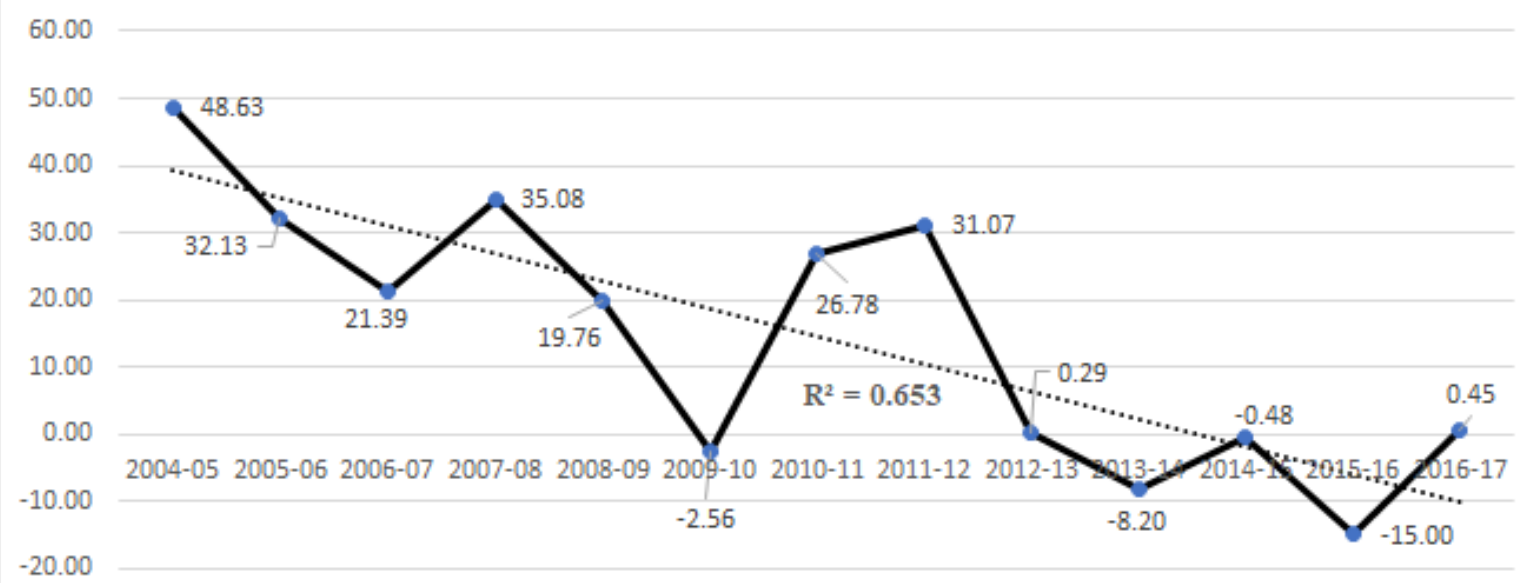

Source: Drawn by the author based on the calculations.

Figure 3 on export and import trend shows that in 2007-08 export growth rate was $28.94 \%$, but due to the impact of the crisis, it reduced to $13.72 \%$ in $2008-09$, and further in 2009-10, it suffered to a negative growth rate which was $-3.49 \%$. Import of Indian economy also declined due to the economic recession and adverse market condition in world trade. The rupee depreciation is also one of the reasons for import contraction during the crisis phase. The import growth was $35.08 \%$ in $2007-08$, which reduced to $19.76 \%$ in $2008-09$ and reached a shallow level in $2009-10$ at $-2.56 \%$ growth rates. This reveals that India's export and import have been adversely affected by the slowdown in the global market. According to International Trade, Economic Survey 2011-12, after the financial crisis, there was a sign of positive and increasing export growth in India due to most of the economies' economic recovery and credit easing policy. Dua \& Tuteja (2015) confirm that reducing export barriers and export promotion policies helped improve the situation. In 2010-11 and 2011-12, export and import represented the positive trends of Indi's international trade. Export increased by $37 \%$ rate and import increased by $26.78 \%$ in 2010-11, but after 2011-12, India's International trade was strongly affected due to exchange rate volatility during 2011-2013 and the Eurozone debt crisis from 2010 to 2012. In 2014-15 and 2015-16 again, the export and import reduced to a negative figure; while the export reached $-0.29 \%$ and $-15.4 \%$, respectively, the import declined to $-0.48 \%$ and $-15 \%$, respectively, due to reduced oil export and import bill reduced due to fall in oil prices. There was a positive export and import growth of $3.20 \%$ and 
$5.40 \%$, respectively, in 2016-17 because of the growth of petroleum and non-petroleum export at $3.2 \%$ and $5.4 \%$, respectively.

Figure 4: Trend of WPI inflation during the period 2004-05 to 2016-17

\section{Trend of WPI inflation (in \%)}

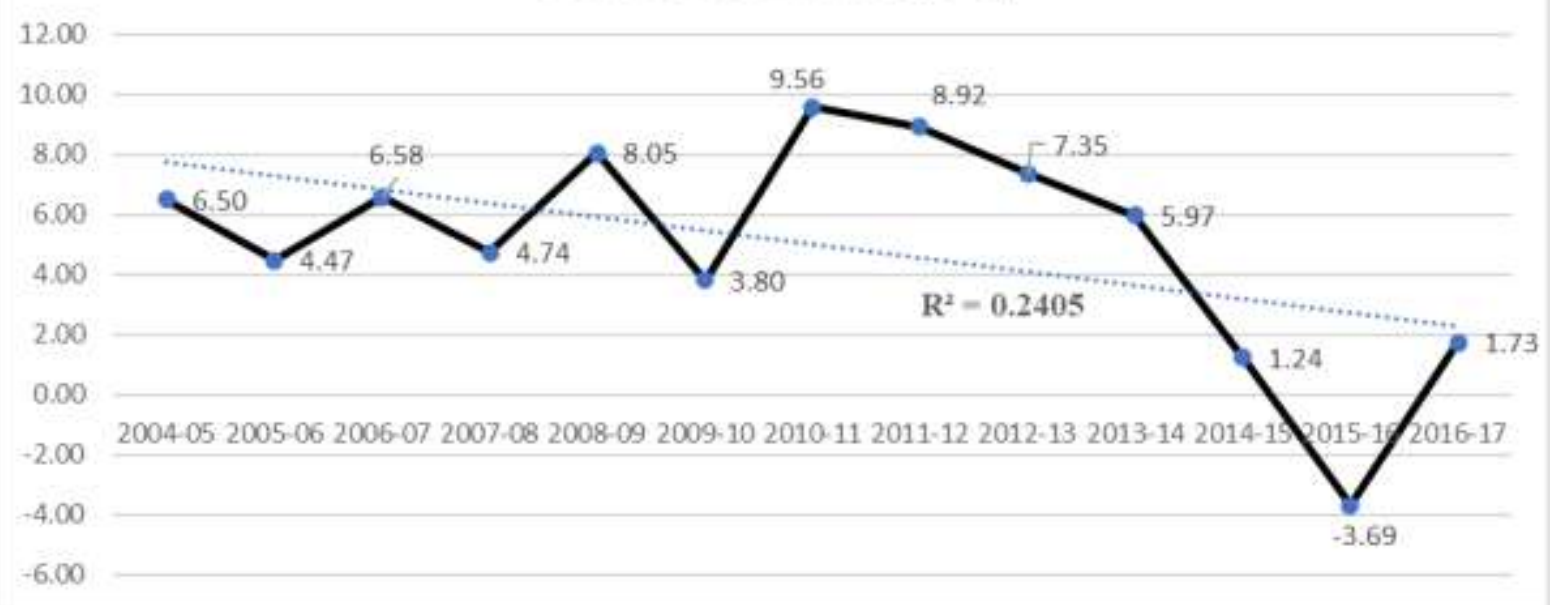

Source: Drawn by the author based on the data collected from .

The trend in the Wholesale Price index (WPI) inflation rate has been downward, as presented in Figure 4. The rupee depreciation influenced the prices of goods, increased import cost, and ultimately affected inflation. As per Price and Inflation, Economic Survey 2008-09, the WPI inflation rate was 4.74\% in 2007-08, but in 2008-09, it reached a very high level at $8.05 \%$ because of increased income of the consumers, which created more demand whereas the supply of food and fuel was in shortage, which increased the inflation rate. In 2009-10, the inflation rate decreased sharply due to the global financial crisis and economic recession. Bhandari \& Majumdar (2011) confirm that due to quantitative easing, low lending rate, increased consumption expenditure, drought in 2009, and uneven rainfall in 2010 has kept the WPI inflation rate increased to $9.56 \%$ in 2010-11. Price and Inflation, Economic Survey (2016-17) explains that the government of India has taken various steps to contain inflation, such as - increased allocation of funds for stabilization of prices in the budget 201718 to reduce the volatility of prices of essential commodities, reduced import duty on potatoes, wheat, and palm oil and imposed $20 \%$ duty on export of sugar.

Figure 5: Trend of change in the foreign exchange rate during 2008

\section{Trend of change in foreign exchange rate}

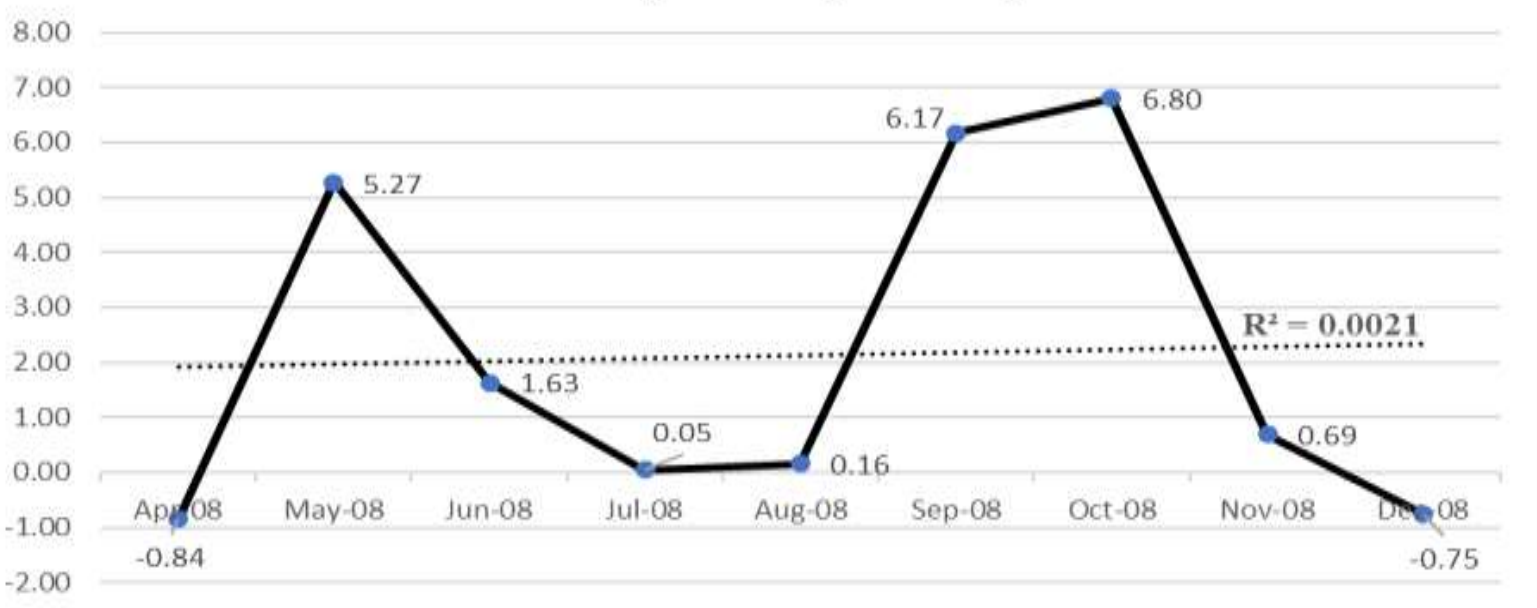

Source: Drawn by the author based on the calculations. 
The rupee's sharp depreciation was caused by a massive withdrawal of investment from the Indian stock market by FIIs and corporate who were converting funds rose locally into foreign currency. Figure 5 presents the change in the foreign exchange rate during 2008. From April to November 2008, the rupee depreciated by approximately $20 \%$. The rupee per unit dollar was Rs. 40.02 in April 2008, and it depreciated to Rs 49 in November 2008.

The above analysis shows that the Indian economy has been affected by the global financial crisis, but the effect was not severe compared to the developed economy. After 2010-11, the crisis's adverse effects have started diminishing. The economic growth was on track because of the counter policy and measures taken by the government of India and the RBI.

\section{Conclusion \& Suggestions}

The effect of the financial crisis started in April 2007, but after the collapse of the Lehman Brothers and some other giant financial services companies, these effects spread throughout the world. Indian economy felt the shock after the Lehman Brothers collapse in September 2008. The country's growth rate declined from $9.70 \%$ in $2007-08$ to $6.70 \%$ in 2008-09. Industrial production and agricultural growth drastically declined, but this negative effect did not prolong due to the initiatives by the government and the RBI to protect the risk effects. The international trade and stock market also suffered due to the financial crisis effects. Export declined, and the fiscal deficit increased at the time of crisis. The Foreign Exchange rate increased at 20\% in a six-month duration from March 2008 to December 2008. The Government and the RBI introduced some monetary and fiscal policies to control the effect of the crisis. The RBI announced liquidity management policies with the appropriate use of financial instruments. Some fiscal measures include expansion of the safety net program, farm loan waiver scheme, and the introduction of the sixth pay commission. Financial stability map and stress test are the other measures introduced by the RBI to limit the financial risk in the economy. Restriction in the foreign flow of capital and capital adequacy norms are the other precautions used in India. There is a need to build a proper financial and fundamental infrastructure to increase the demand for goods and services in the economy and the open market and accelerate infrastructural development and growth. The banks should promote financial inclusion and literacy activities to increase saving and banking habits in rural India.

The study discusses the important variables during the crisis and relates the same with relevant literature. The findings open up the scope for future studies. The main limitation of this study is that it concentrates on the impacts of the crisis on the Indian economy. However, the findings of this study will assist the researchers in correlating the findings with a sample of a few more emerging and developed nations to provide insights into how the global financial crisis impacted them differently.

\section{Declaration of Conflicting Interests}

The authors declared no potential conflicts of interest with respect to the research, authorship, and/or publication of this article.

\section{Funding information}

The authors declared no financial support for the research, authorship, and/or publication of this article.

\section{Acknowledgements: None}

\section{References}

Bera, S. (2017). Food Grain Production estimated at record 272 million tonnes in 2016-17. Livemint (15 February 2017). Available at https://www.livemint.com/Politics/f2etZiWEzUlq4I4J490UjM/Record-272million-tonnes-food-grains-in-201617-agricultur.html 
Bhandari, B., \& Mazumdar, R. (2011). Inflation over the decades. In The Hindu Business Line (30 June 2011). Available at https://www.thehindubusinessline.com/opinion/inflation-over-the-decades/article22995843.ece

Bhatt, R. K. (2011). Recent Global Recession and Indian Economy: An Analysis. International Journal of Trade, Economics and Finance, 2(3), 212-217. https://doi.org/10.7763/ijtef.2011.v2.105

Das, A. (2012). Global Economic Crisis: Causes, Impact on Indian Economy, Agriculture and Fisheries. International Journal of Agriculture Sciences, 4(4), 221-226. https://doi.org/10.9735/0975-3710.4.4.221226

Deshpande, T. (2014). State of Agriculture in India. PRS Legislative Research, 113, 1-28. Available at https://prsindia.org/files/policy/policy_analytical_reports/State\%20of\%20Agriculture\%20in\%20India.pdf

Dua, P. and Tuteja, D. (2015). Global Recession and Eurozone Debt Crisis : Impact on Exports of China and India. In Working Paper No. 242. Centre for Development Economics, Delhi School of Economics. Available at https://ideas.repec.org/p/cde/cdewps/242.html

Economic Survey 2008-2009. Ministry of Finance, Government of India. Prices and Monetary Management.

Economic Survey 2011-2012. Ministry of Finance, Government of India. Available at https://www.indiabudget.gov.in/budget2012-2013/es2011-12/estat1.pdf

Economic Survey 2012-2013, Ministry of Finance, Government of India

Economic Survey 2013-2014. In Ministry of Finance, The Government of India. http://indiabudget.nic.in/es2013-14/estat1.pdf

Economic Survey 2016-2017. Ministry of Finance, Government of India. Available at https://www.indiabudget.gov.in/budget2017-2018/es2016-17/echapter.pdf

Fiscal Rules : Lessons from the States. (2017). In Economic Survey 2016-17.113-127.

Gupta, S., \& Singh, K. (2016). Fiscal Deficit and its Trends in India. International Journal of Business and Management Invention, 5(11), 63-75. www.ijbmi.org

Kumar, R. M., Joseph, D. Allex, P. Vashisht, and D. Banerjee. 2009. The Outlook of Indian Economy $2008-09$ and 2009-10. Indian Economic Outlook 2008-09 and 2009-10. ICSSR Working Paper no. 234. Available at https://icrier.org/pdf/WorkingPaper234.pdf

Mishkin, F. S. (1997). The Causes and Propagation of Financial Instability: Lessons for Policymakers. In Maintaining Financial Stability in a Global Economy, Federal Reserve Bank. 55-96

Mohan, R. (2009). Global Financial Crisis : Causes, Impact, Policy Responses and Lessons. Working Paper no. 407, Stanford Centre for International Development. Available at https://www.bis.org/review/r090506d.pdf

Pandey, D.K. and, Jaiswal, A. K. (2014). The myths and realities vis-à-vis the financial crisis in the U.S. economy. Business Analyst, 34(2), 129-137. https://doi.org/10.5281/zenodo.4698537

Prasad, A., \& Reddy, C. P. (2009). Global Financial Crisis and its Impact on India. Journal of Social Sciences, 21(1), 1-5. https://doi.org/10.1080/09718923.2009.11892744 